\title{
Asymmetric rolling process
}

\section{Postopek asimetričnega valjanja}

\author{
Peter Fajfar ${ }^{1, *}$, Alenka Šalej Lah', Jakob Kraner', Goran Kugler ${ }^{1}$ \\ ${ }^{1}$ University of Ljubljana, Faculty for Natural Sciences and Engineering, Department for Materials and Metallurgy, \\ Aškerčeva cesta 12, SI-1000 Ljubljana, Slovenija \\ *peter.fajfar@omm.ntf.uni-lj.si
}

\begin{abstract}
Asymmetric rolling is a novel technique used to control both the texture and the grain refinement of metallic materials. The aim of asymmetric rolling is to apply a large shear strain uniformly through the thickness of the plate, by maintaining a high degree of friction between the sheet and the rolls. It can be used to improve the formability of material. One of the advantages of asymmetrical rolling is that the rolling force and torque can be decreased. The methods used for the asymmetric rolling are single roll drive, different work roll speeds, different work roll diameters or different lubricated work roll surfaces.
\end{abstract}

Key words: asymmetric rolling, microstructure, texture, mechanical properties

\section{Izvleček}

Asimetrično valjanje je novejša tehnika preoblikovanja, ki se uporablja za kontrolo teksture in za zmanjšanje zrnatosti valjanega materiala. Pri asimetričnem valjanju nastanejo zaradi velikega trenja na stiku valjanega materiala in valjev velike strižne deformacije po celotnem preseku valjanca. $S$ to tehniko se lahko izboljšajo preoblikovalne lastnosti materiala. Ena od prednosti asimetričnega valjanja je tudi zmanjšanje sile in momenta valjanja. Asimetrično valjanje lahko izvajamo na naslednje načine: $\mathrm{z}$ le enim gnanim valjem, različnima hitrostima valjev, različnima premeroma valjev ali pa z (ne)uporabo različnih lubrikantov na površini valjev.

Ključne besede: asimetrično valjanje, mikrostruktura, tekstura, mehanske lastnosti 


\section{Introduction}

Asymmetric rolling (ASR) is a special and fairly new technique of metal rolling; however, the first research on this technique dates back to the middle of the past century [1]. Negligible numbers of scientific papers have been published until the beginning of the year 2000 when ASR became more interesting for research [2-17]. A significant increase in publications has been noticed in the past few years [18-34]. They deal with hot and cold rolling, rolling of steels [13], aluminium [2-6, 8, 12, 16, 20-22, 29, 31, 34], titanium [30], magnesium $[16,23]$ and their alloys, as well as flat, wire [25] and rod rolling [28].

The basic characteristic of the ASR process is rolling with different circumferential velocities of the upper and the lower work rolls. It can be carried out using several approaches as follows:

- different diameters of the work roll;

- different work roll velocities;

- single roll drive;

- different lubricated work roll surfaces.

ASR is a relatively novel technique only with reference to the improvement of the materials' formability; it is actually one of the oldest flat rolling techniques using three-high rolling mills, invented to enable better plate profiles in comparison with the two-high rolling mill. In the beginning of the 19th century the first three-high rolling mills were introduced in plate-rolling production. They have higher resistance to roll bending in comparison to the two-high rolling mills. In the middle of the 19th century, Lauth [35] improved the existing three-high rolling mill. In the Lauth rolling mill, the lower roll was fixed; the middle roll, which was smaller than the upper and lower rolls, was raised and lowered by a power-operated lever alternately as the piece passed under or over it. The draft was achieved by adjusting the upper roll using a screw gear. The small middle roll was an idler roll, and it was set in rotation by the friction developed by the upper and lower rolls. It was not subject to bending stress, as it was always in contact with one or other of the large rolls. The mill tables were used to deliver the rolling material by raising or lowering depending on the rolling direction [35]. The ASR

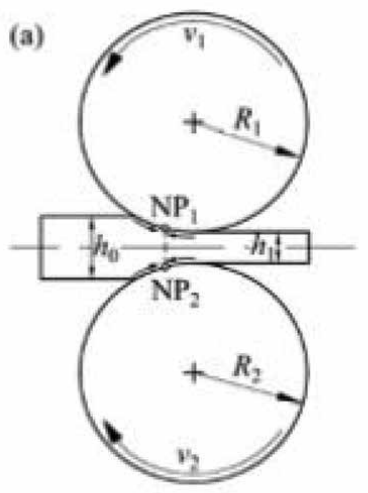

(b)
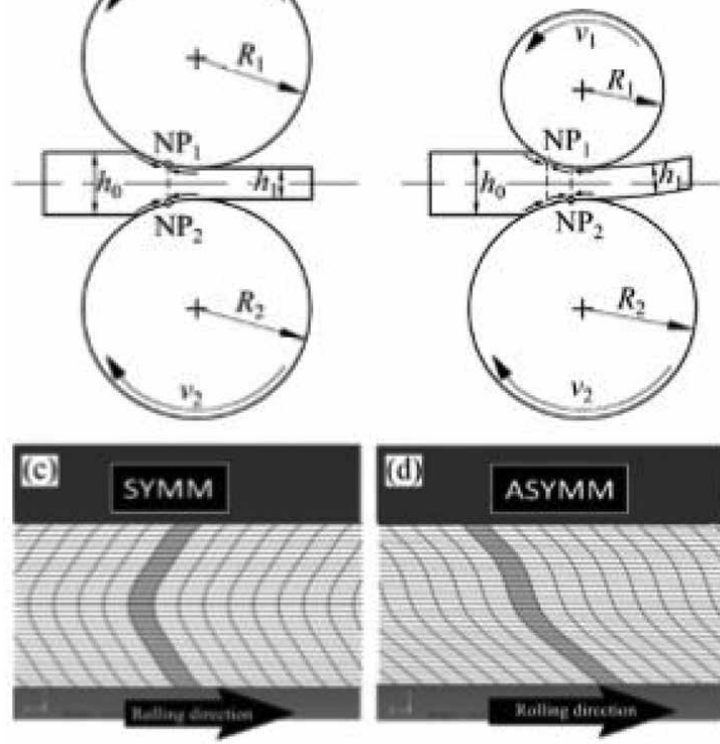

(d) ASYMM

Figure 1: Schematic pictures: (a) symmetric rolling with $R_{1}=R_{z^{\prime}}$ $v_{1}=v_{2}$; (b) ASR with $R_{1}<R_{2}, v_{1}<v 2$; (c) and (d) metal flow exiting the roll gap in (a) and (b), respectively [13].

technique in three-high rolling mill technology is characterised by different roll diameters. The tendency of rolling piece curvature is reduced by the inclination of the rolling mill table.

In the case of ASR, the neutral line in the deformation cone is shifted in comparison with symmetric rolling. The point of the neutral line at the slower work roll is moved to the entry side and the point of the neutral line at the faster work roll to the exit side of the deformation cone (Figure 1). Friction stresses that are in the opposite directions at the upper and lower work roll surfaces generate additional shear strains throughout the rolled piece's thickness. The deformation mode is no more single compression, but a combined mode of compression and shear. This additional shear strains cause a change in the textures and microstructures of the rolled materials. In comparison to the conventional rolling (CR) technique, the rolling force and rolling torque are significantly reduced. This indirectly allows higher deformation and hence the formation of finer-grained microstructures. Such texture modifications can be of significant technological interest because the resulting textures can be beneficial to mechanical anisotropy and consequently the formability. 

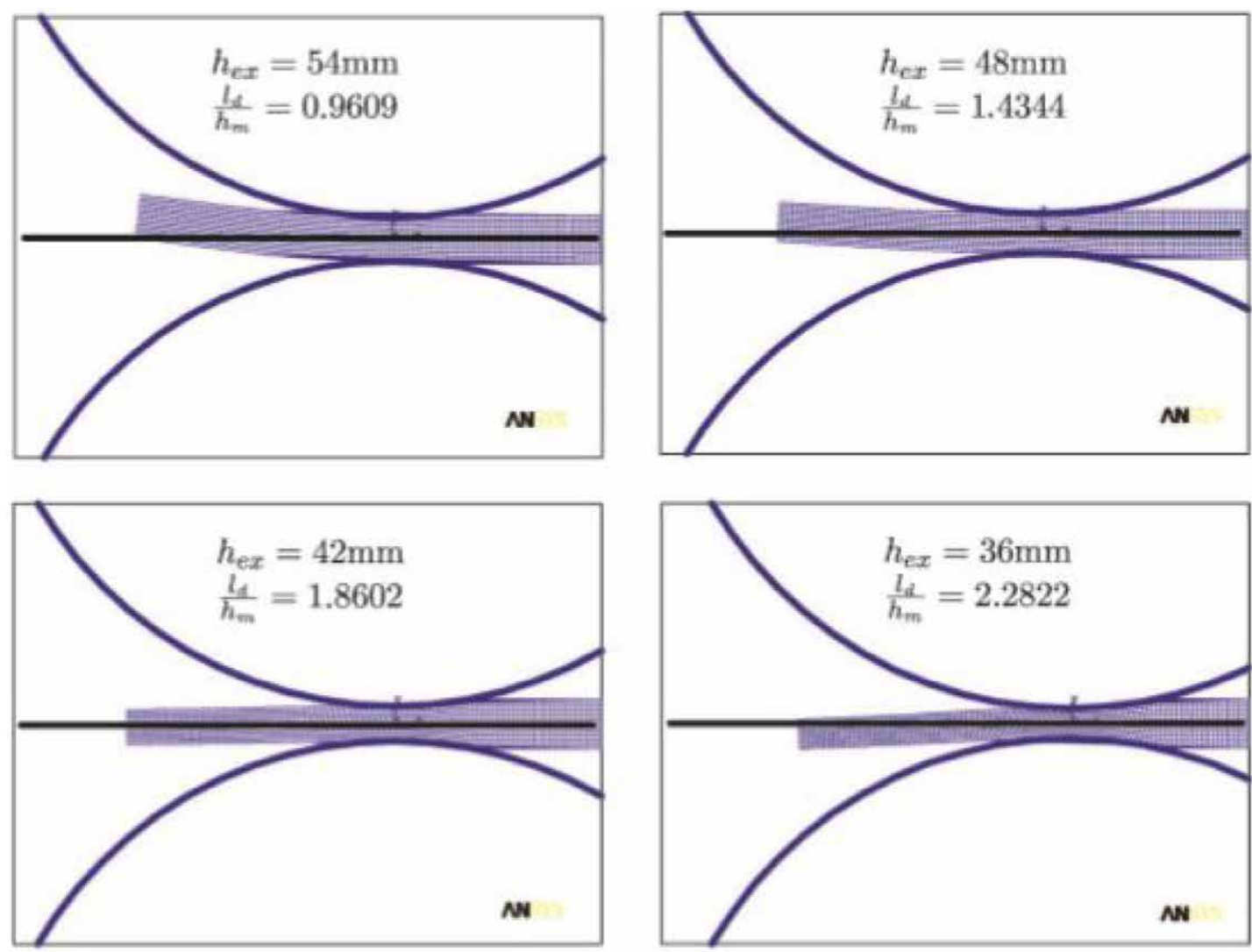

Figure 2: FEM simulations for a constant entry thickness $h_{e n}=60 \mathrm{~mm}[6]$.

\section{Technological parameters}

\section{Curvature}

Due to ASR conditions, the plate may bend upwards or downwards. The curvature of the plate (ski effect) can be troublesome to production. It can cause damage to the mill rolls, housing and run-out tables, as well as causing production delays due to the difficulty of running into the rolling gap during the following pass. Differences in roll diameter of about $2.5 \%$ also generate a pronounced strip curvature [15]. The curvature depends not only on the asymmetries themselves but also on the geometry of the roll gap. The roll gap geometry is characterised by the shape factor, which is defined as the ratio between the arc length of contact and the medium plate thickness. In the case of different work roll velocities, it is expected that the plate will bend towards the slower work roll. Kiefer and Kugi [6] found that this is valid only for the smaller shape factors. For larger shape factors, the curvature changes sing and the plate bends towards the faster work roll. The results of finite a)

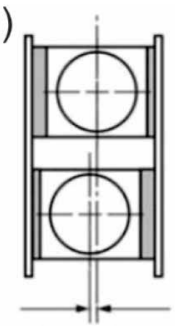

horizontal shifting b)

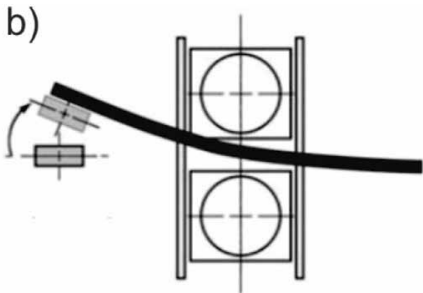

table adjustment

Figure 3: (a) Horizontal shifting of work rolls; (b) adjustment of bar entry position [15].

element method (FEM) simulations, wherein the lower roll velocity is $2.1 \mathrm{~m} \cdot \mathrm{s}^{-1}$ and is $5 \%$ higher than that for the upper roll, are presented in Figure 2 [6]. The value of the shape factor at the turning point between ski-up/ski-down conditions is 1.86 .

Other suggested methods to avoid plate curvature are partial roll lubrication, horizontal work roll shifting or different inclinations of the plate at entry, as shown in Figure 3 [15]. Partial roll lubrication is an effective method to control the 


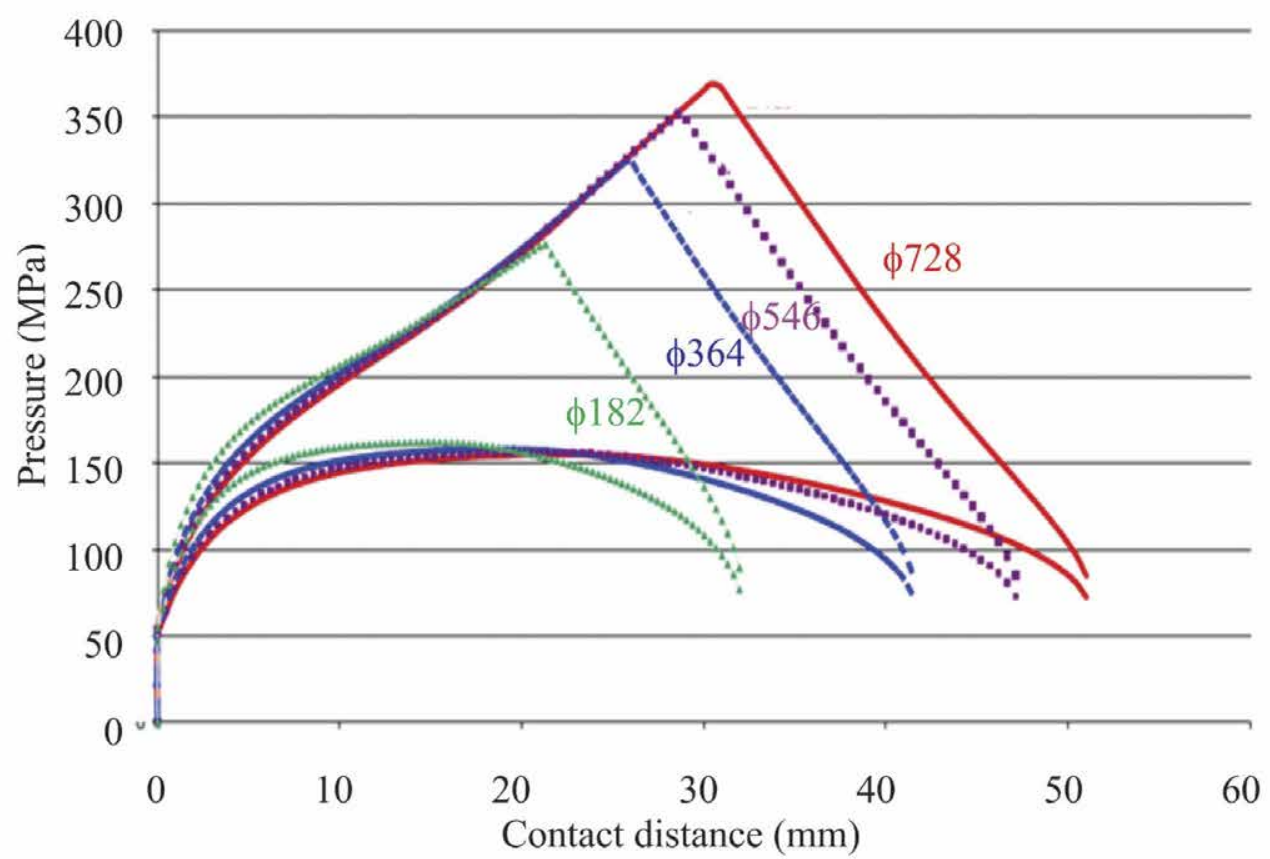

Figure 4: Impact of the diameter on the pressure distribution [15].

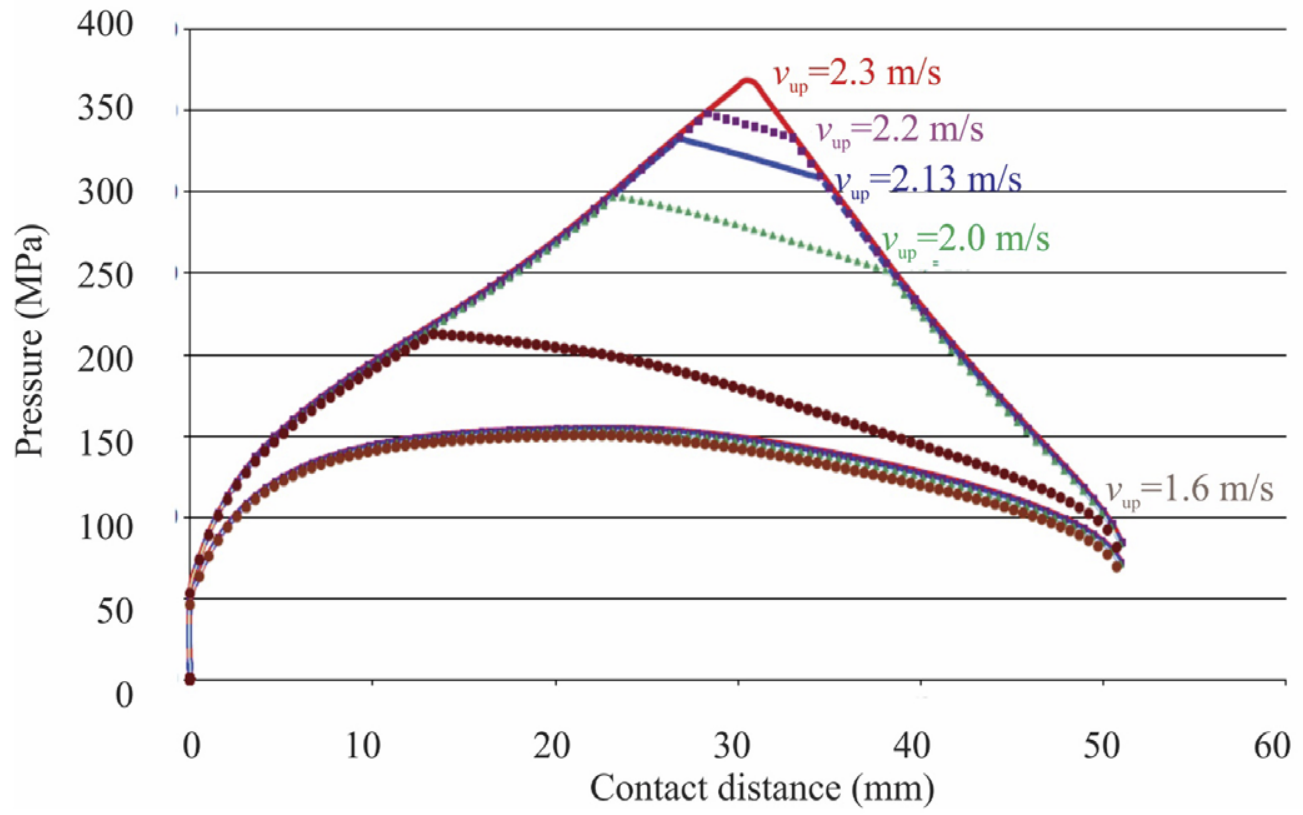

Figure 5: Impact of different roll speeds on the pressure distribution [15].

ski effect and it is nearly independent of the roll gap ratio and other factors. The plate bends downwards on the roller table if the upper roll is lubricated and upwards if the lower roll is lubricated. The roll shifting method is quite questionable in practical application. With increasing difference in the diameters of the upper and lower work rolls, the dislocation of the arc of contact between both rolls becomes continuously larger. If the roll shifting is greater than the contact length, there is no more common contact angle. From this value on, no rolling conditions can create shear deformations. With the feeding table inclination, the bar entry 


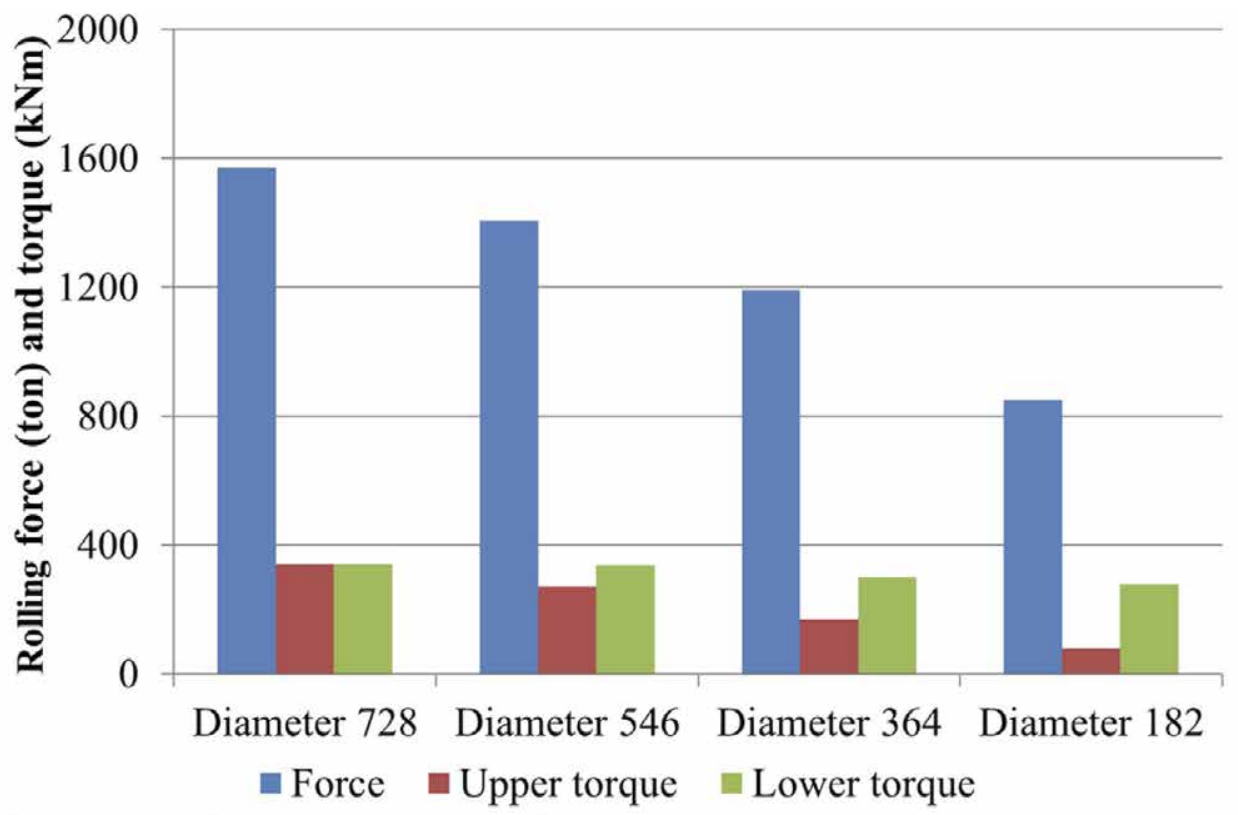

Figure 6: Impact of the diameter on the rolling force and torque [15].

position is changed. In the case of equal upper and lower roll diameters, the contact angle of the lower roll is a bit larger, and this results in bending of the plate upwards [15].

\section{Rolling force and torque}

Another advantage of asymmetrical rolling is that the rolling force and torque can be decreased, which saves the required energy to accomplish the process.

The model based on the slab method was used to investigate the influence of roll diameters (Figure 4) and roll velocities (Figure 5) on the normal pressure distribution over the contact arc length [15]. For the evaluation of the impact of the diameter, the lower roll diameter remained constant, but the upper roll diameter was reduced in four steps (Figure 4). The same speed was used for both rolls. The decrease in the rolling force is due to a decrease in both the maximum pressure and the contact length. In the case of equal work roll diameter and decreasing upper roll speed, the maximum pressure is decreasing, but the contact length remains constant (Figure 5). The impact of the diameter on the rolling force and torque is presented in Figure 6. With increasing roll diameter, the decrease of force is clearly visible. The asymmetrical effect is shown through a differ-

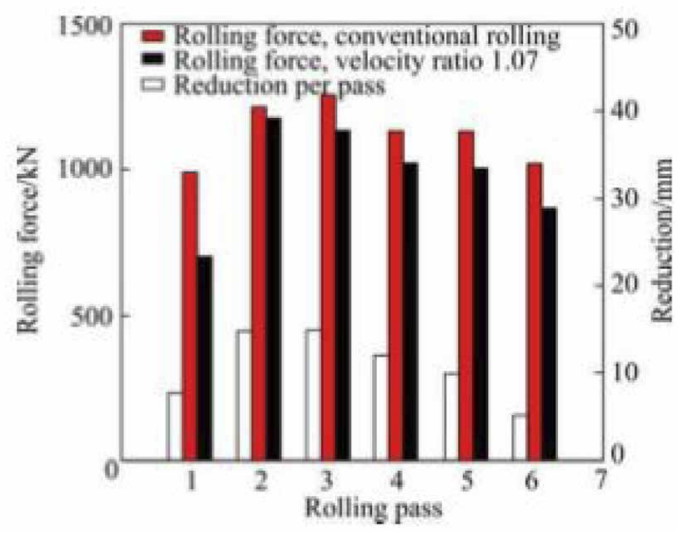

Figure 7: Comparison of rolling force with conventional rolling and asymmetric rolling [21].

ence in the value for the torques. The side with the smallest diameter has the lowest torque as it has smaller level arm [15].

Zuo et al [21] reported that in the case of aluminium hot rolling, the forces of the ASR were 5\%-30\% lower than those of symmetric rolling (Figure 7). Asymmetrical rolling was achieved with roll diameters with which velocity ratios of 1.07 and 1.20 were obtained.

Similar results were obtained by hot rolling of steel samples [13]. The diameter ratios between the upper and lower rolls were 1.00, 1.05 and 1.11 . The values of 1.05 and 1.11 were 


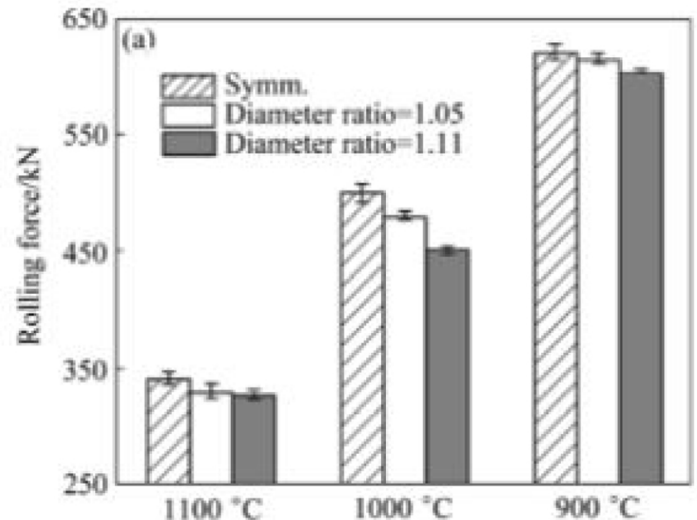

Figure 8: Rolling force according to different diameter ratios and rolling temperatures [13].

chosen because they are not only available in the laboratory but can also be applied in actual industrial practice. The highest rolling force reduction was up to $10 \%$ (Figure 8).

\section{Material properties}

\section{Microstructure}

In ASR, in the region between the two neutral points (Figure 1b), friction stresses have opposite senses on both surfaces, which results in shear strain distribution through the thickness of the workpiece. This can significantly change the metal deformation stream and can influence the microstructure evolution.

Zuo et al. [21] investigated the evolution of microstructures through the thickness of hotrolled aluminium plates for both conventional and ASR (Figure 9). In the case of CR, a finegrained microstructure at the upper and lower surfaces and a coarse microstructure in the centre are found. For asymmetric hot rolling process with the velocity ratio of 1.70 , the microstructure becomes finer and more uniform. With further increase in the velocity ratio to 1.20 , the microstructure is still more uniform and finer than that of the symmetrically hotrolled plate; however, the microstructure becomes slightly coarser than that of the plate rolled with the velocity ratio of 1.07 . This could be due to additional shear deformation and further growth of the recrystallised (REX) grains. Similar results were obtained for hot rolling of magnesium alloys [23]. Using a laboratory rolling mill, as-cast magnesium alloy plates were

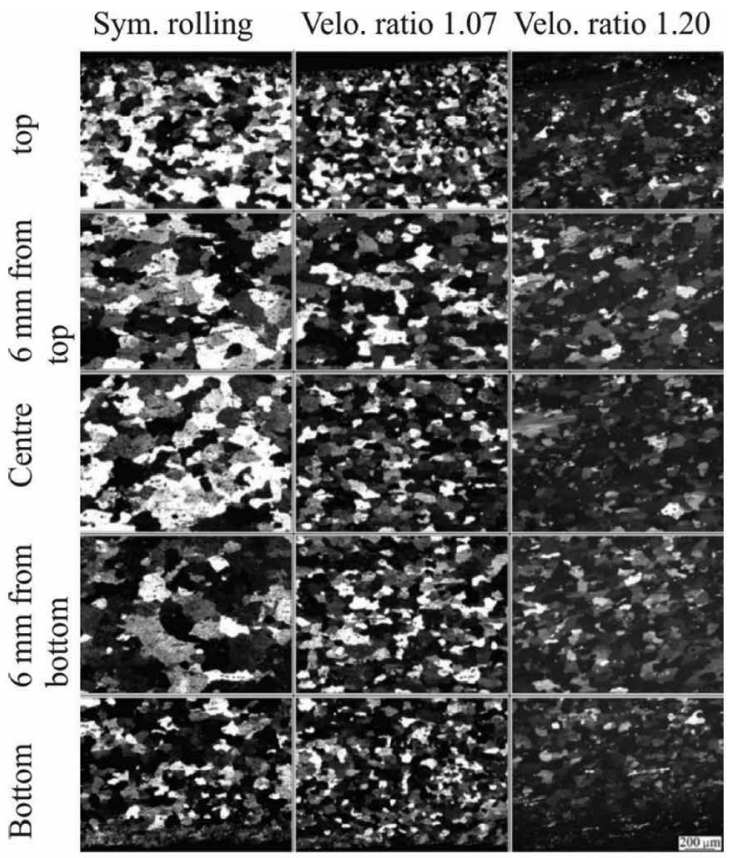

Figure 9: Microstructures of hot-rolled plates with conventional rolling and asymmetric rolling [21].

rolled in both symmetrical and asymmetrical manner at the temperature of $300^{\circ} \mathrm{C}$. Total deformation after two passes was 0.67. Before rolling, the speed ratio between the upper and lower rolls was selected at 1.25 . Figure 10 shows the microstructures of the as-cast condition and after homogenisation heat treatment, symmetric rolling and asymmetric rolling of AZ31 magnesium alloy plates. After the heat treatment, equiaxed grain structure was formed, and the grain size was refined to $19 \mathrm{~mm}$ (Figure 10b). For the symmetrically rolled sample, the average grain size achieved was $10 \mathrm{~mm}$ (Figure 10c) and for the asymmetrically rolled sample, it was $0.7 \mathrm{~mm}$ (Figure 10d).

\section{Mechanical properties}

ASR can be used to change the crystallographic texture and some mechanical properties of a material. In recent years, numerous authors $[2-4,22,31]$ have reported that the use of ASR improved the formability of rolled aluminium sheet by introducing an intense shear deformation and an associated shear texture. One of the major disadvantages of aluminium alloys is their low deep drawability, which depends on various material properties such as plastic $R$ or planar anisotropy $|\Delta R|$. High plastic anisotropy may lead to increase in the resistance to 

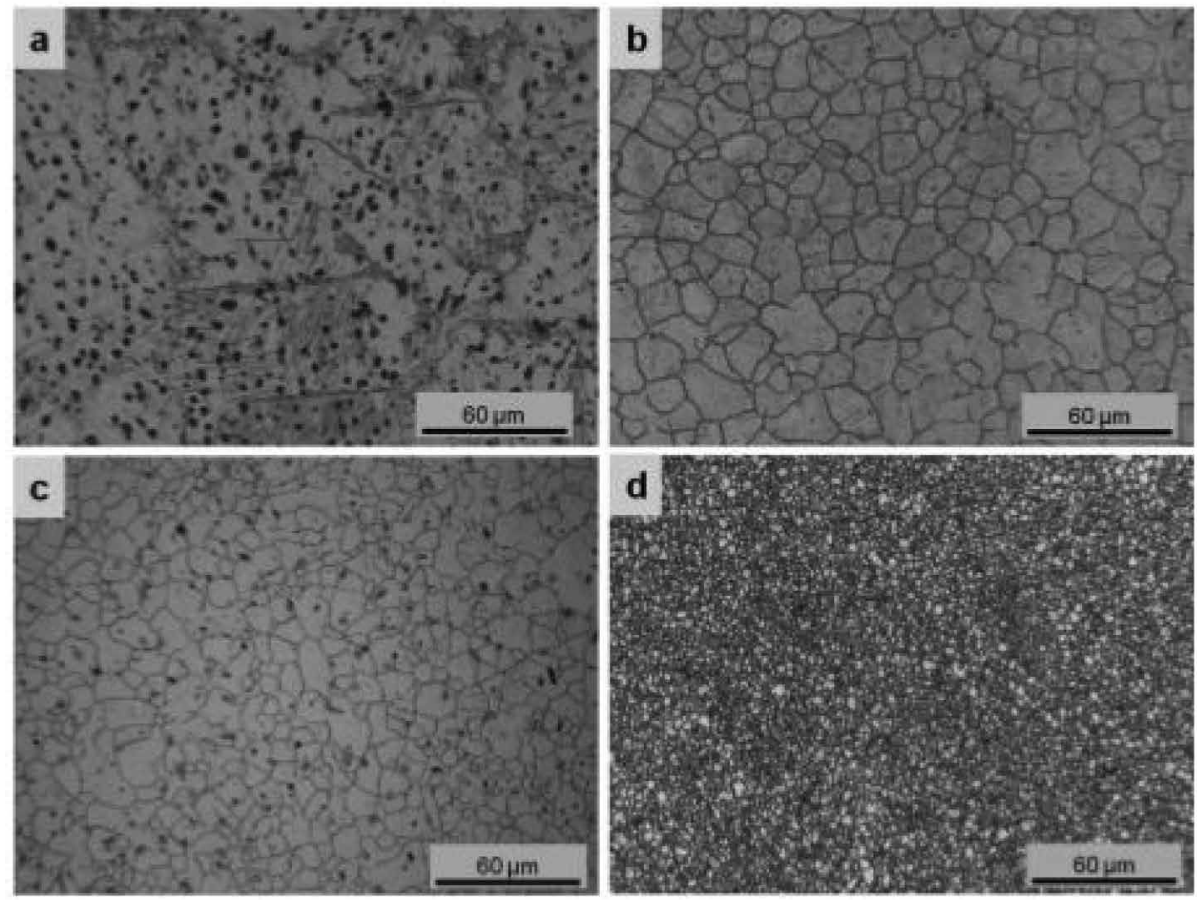

Figure 10: Plain view microstructures of (a) as-cast plates and after (b) homogenisation at $425^{\circ} \mathrm{C}$ for 6 hours, (c) symmetric rolling and (d) asymmetric rolling of AZ31 magnesium alloy sheets [23].

Table 1: Measured R-values, normal and planar anisotropy [20].

\begin{tabular}{cccccc} 
& $\boldsymbol{R}_{\mathbf{0}}$ & $\boldsymbol{R}_{\mathbf{4 5}}$ & $\boldsymbol{R}_{\mathbf{9 0}}$ & $\mathbf{R}$ & $|\Delta \boldsymbol{R}|$ \\
\hline REX & 0.56 & 0.35 & 1.1 & 0.59 & 0.48 \\
\hline CR & 0.64 & 0.8 & 0.57 & 0.70 & 0.19 \\
\hline C-ASR & 0.96 & 1.12 & 0.70 & 0.98 & 0.28 \\
\hline R-ASR & 0.76 & 1.05 & 0.66 & 0.89 & 0.34 \\
\hline
\end{tabular}

thinning. In addition, the low planar anisotropy may result in increasing the resistance to earing in deep drawing applications.

Tamini et al. [20] investigated the deep drawability of AA-5182 aluminium alloy through improvement of the crystallographic texture by ASR. The experimental $R$-values obtained in the uniaxial tensile test for all rolling conditions are listed in Table 1. The experimental results indicate that $R$ is higher in the specimen produced by continuous ASR (C-ASR) and reverse ASR (R-ASR) in comparison with CR and REX samples. However, the absolute value of $|\Delta R|$ increases slightly by applying the ASR process, but the value is still smaller than that in the REX sample.

Inoue [16] performed a combination of symmetric hot (HR), asymmetric hot (AHR), warm symmetric (WR) and warm asymmetric (AWR) rolling of AZ31B magnesium alloy plates. Warm rolling processes (WR + AWR) were conducted at $573 \mathrm{~K}$, and hot rolling (HR + WHR) at $723 \mathrm{~K}$. Reduction per pass was $10 \%$. For the ASR, a diameter ratio of 1.5 was used. The final sheet product of all rolling processes was finally annealed at $573 \mathrm{~K}$ for 1800 seconds in argon atmosphere.

Figure 11 shows the results of the tensile tests for rolled and annealed sheets. Most of the samples have the highest proof stress in the transverse direction in relation to the inclination of the basal plane towards the rolling direction, but all samples have the highest elongation at the direction $45^{\circ}$ to the rolling direction. The proof stress of hot-rolled sheets (HR, AHR and $\mathrm{HR}+\mathrm{AHR}$ ) is considerably lower than that of a warm-rolled sheet (WR), but their elongation becomes higher inversely. In particular, the 


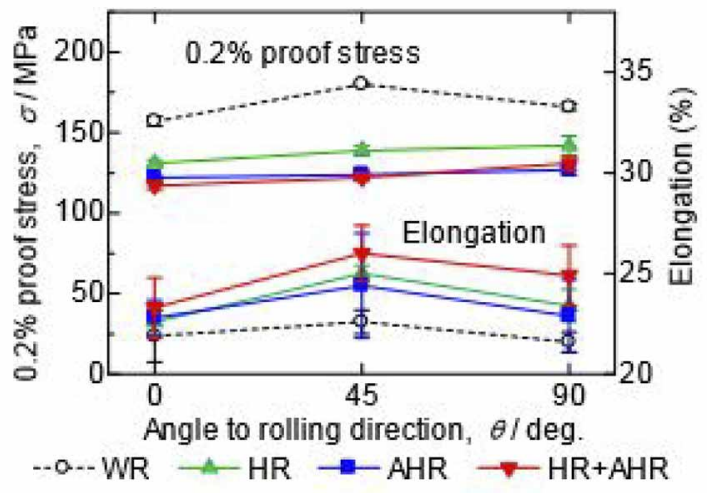

Figure 11: Proof stress (0.2\%) and elongation as a function of the angle to the rolling direction for AZ31 Mg sheets fabricated by various rolling processes and annealed at $573 \mathrm{~K}$ for 1800 seconds [16].

symmetric/asymmetric combination rolling process by HR + AHR results in higher ductility and moderate yield strength of about $120 \mathrm{MPa}$.

\section{Conclusion}

ASR has a large potential importance for industrial applications. It can be conducted using existing rolling mills, commonly used in symmetric rolling. It reduces the applied rolling pressure and torque. The appearing shear deformation produces a more homogeneous microstructure and modifies the resulting texture. ASR can be used to improve the formability of the material irrespective of thickness. Rolling under asymmetrical conditions causes the rolled slab to bend towards the direction of one of the rolls. This so-called ski effect is undesired, because it hinders the further transport of the material and is a potential danger for the machine components in the proceeding processes. The impact of asymmetrical rolling is more pronounced in the cases of rolling of thinner rolling pieces and use of different work roll speeds.

\section{Acknowledgments}

This work was funded by the program MARTINA, supported by Slovenian Ministy of education, science and sport and European Regional Development Fund.

\section{References}

[1] Buxton, S.A.E., Browningt, S.C. (1972): Turn-up and turn-down in hot rolling. Journal of Mechanical Engineering Science, 14(4), pp. 245-254.

[2] Jin, H., Lloyd, D.J. (2004): The Tensile Response of a Fine-Grained AA5754 Alloy Produced by Asymmetric Rolling and Annealing. Metallurgical and Materials Transactions A, 35 A, pp. 997-1006.

[3] Kang, S.B., Min, B.K., Kim, H.W., Wilkinson, D.S., Kang, J. (2005): Effect of Asymmetric Rolling on the Texture and Mechanical Properties of AA6111-Aluminium Sheet. Metallurgical and Materials Transactions A, 36A, pp. 3141-3149.

[4] Jin, H., Lloyd, D.J. (2005): The reduction of planar anisotropy by texture modification through asymmetric rolling and annealing in AA5754. Materials Science and Engineering A, 399, pp. 358-367.

[5] Kawałek, A. (2007): The analysis of the asymmetric plate rolling process. Journal of Achievements in Materials and Manufacturing Engineering, 23(2), pp. 63-66.

[6] Kiefer, T., Kugi, A. (2008): An Analytical Approach for Modelling Asymmetrical Hot Rolling of Heavy Plates. Mathematical and Computer Modelling of Dynamical Systems, 14, pp. 1-19.

[7] Sidor, J., Miroux, A., Petrov, R., Kestens, L. (2008): Microstructural and crystallographic aspect of conventional and asymmetric rolling processes. Acta Materialia, 56, pp. 2495-2507.

[8] Sidor, J., Miroux, A., Petrov, R., Kestens, L. (2008): Controlling the plastic anisotropy in asymmetrically rolled aluminium sheets. Philosophical Magazine, 88, pp. 3779-3792.

[9] Roumina, R., Sinclair, C. (2008): Deformation geometry and through-thickness strain gradients in asymmetric rolling. Metallurgical and Materials Transaction A, 39(2495), pp. 2495-2503.

[10] Zhang, S.H., Zhao, D.W., Gao, C.R., Wang, G.D. (2012): Analysis of asymmetrical sheet rolling by slab method. International Journal of Mechanical Sciences, 65, pp. 168-176.

[11] Nikolaev, V.A., Vasilyev, A.A. (2010): Analysis of Strip Asymmetrical Cold Rolling Parameters. Metallurgical and Mining Industry, 2, pp. 405-412.

[12] Jin, H., Lloyd, D.J. (2010) The different effects of asymmetric rolling and surface friction on formation of shear texture in aluminium alloy AA5754. Materials Science and Technology, 26(6), pp. 754-760.

[13] Liu, J., Kawalla, R. (2012): Influence of asymmetric hot rolling on microstructure and rolling force with aus- 
tenitic steel. Transactions of Nonferrous Metals Society of China, 22, pp. 504-511.

[14] Anders, D., Münker, T., Artel, J., Weinberg, K. (2012): A dimension analysis of front-end bending in plate rolling applications. Journal of Materials Processing Technology, 212, pp. 1387-1398.

[15] Nilsson, A., Salvator, I., Putz, P.-D., Goldhahn, G., Malbrancke, J. (2012): Using asymmetrical rolling for increased production and improved material properties. European Union.

[16] Inoue, H. (2012): Texture Control of Aluminium and Magnesium Alloys by the Symmetric/Asymmetric Combination Rolling Process. Materials Science Forum, 702-703, pp. 68-75.

[17] Azbanbayev, E., Isagulov, A., Ashkeyev, Z. (2013): Mathematical simulation of the process of rolling in the back taper rolls. In: 22nd International Conference on Metallurgy and Materials, 15.5.-17.5.2013, Brno, Czech Republic.

[18] Wronski, S., Wierzbanowski, K., Wronski, M., Bacroix, B. (2014): Three dimensional analysis of asymmetric rolling with flat and inclined entry. Archives of Metallurgy and Material, 59(2), pp. 585-591.

[19] Aljabri, A., Jiang, Z., Wie, D. (2014): Analysis of thin strip profile during asymmetrical cold rolling with roll crossing and shifting mill. Advanced Materials Research, 894, pp. 212-216.

[20] Tamini, S., Correia, J.P., Lopes, A.B., Ahzi, S., Barlat, F., Gracio, J.J. (2014): Asymmetric rolling of thin AA5182 sheet: Modellingand experiments. Materials Science and Engineering A, 603, pp. 150-159.

[21] Zuo, Y.-b., Fu, X., Cui, J.-z., Tang, X.-y., Mao, L., Li, L., Zhu, Q.-f. (2014): Shear deformation and plate shape control of hot-rolled aluminium alloy thick plate prepared by asymmetric rolling process. Transactions of Nonferrous Metals Society of China, 24, pp. 2220-2225.

[22] Dutta, S., Kaiser, M.S., (2014): Effect of asymmetric rolling on formability of pure aluminium. Journal of Mechanical Engineering, 44(2), pp. 94-99.

[23] Ucuncuoglu, S., Ekerim, A., Secgin, G.O., Duygulu, 0. (2014): Effect of asymmetric rolling process on the microstructure, mechanical properties and texture of AZ31 magnesium alloys sheet produced by twin roll casting technique. Journal of Magnesium and Alloys, 2, pp. 92-98.

[24] Pesin, A., Pustovoytov, D., Sverdlik, M. (2014): Influence of Different Asymmetric Rolling Processes on Shear Strain. International Journal of Chemical, Molec- ular, Nuclear, Materials and Metallurgical Engineering, 8(6), pp. 477-479.

[25] Parvizi, A., Pasoodeh, B., Abrinia, K., Akbari, H. (2015): Analysis of curvature and width of the contact area in asymmetrical rolling of wire. Journal of Manufacturing Processes, 20, pp. 245-249.

[26] Lee, K., Han, J., Park, J., Kim, B., Ko, D. (2015): Prediction and control of front-end curvature in hot finish rolling process. Advances in Mechanical Engineering, 7(11), pp. 1-10.

[27] Alexa, V., Ratiu, S., Kiss, I. (2015): Metal rolling - Asymmetrical rolling process. In: International Conference on Applied Sciences, pp. 1-10.

[28] Pesin, A., Chukin, M., Pustovoytov, D. (2015): Finite Element Analysis of Symmetric and Asymmetric Threeroll Rolling Process. MATEX Web of Conference, 26, 03006.

[29] Liu, X., Liu, X.-h., Song, M., Sun, X.-k., Liu, L.-z. (2016): Theoretical analysis of minimum metal foil thickness achievable by asymmetric rolling with fixed identical roll diameters. Transactions of Nonferrous Metals Society of China, 26, pp. 501-507.

[30] Jianping, L., Zhenguang, L., Jing, L. (2016): Influence of Asymmetric Hot Rolling on Microstructure and Mechanical Property of Ti-6Al-4V Alloy Sheet. Rare Metal Materials and Engineering, 45(5), pp. 1168-1174.

[31] Bintu, A., Vincze, G., Picub, R.C., Lopes, A.B. (2016): Effect of symmetric and asymmetric rolling on the mechanical properties of AA5182. Materials and Design, 100, pp. 151-156.

[32] Minton, J.J., Cawthorn, C.J., Brambley, E.J. (2016): Asymptotic analysis of asymmetric thin sheet rolling. International Journal of Mechanical Sciences, 113, pp. 36-48.

[33] Ma, B., Li, C., Wang, J., Cai, B., Sui, F. (2016): Influence of asymmetric hot rolling on through-thickness microstructure gradient of Fe-20Mn-4Al-0.3C non-magnetic steel. Material Science and Engineering, A671, pp. 190-197.

[34] Diniz, S.B., Benatti, E.A., Paula, A. dos S., Bolmaro, R.E., da Silva, L.C., Meirelles, B.G. (2016): Microstructural evaluation of an asymmetrically rolled and recrystallized 3105 aluminium alloy. Journal of Materials Research and Technology, 5(2), pp. 183-189.

[35] History of Steelworks' Plant and Equipment [online]. Talk Talk, 2017, [cited 1/7/2017]. Available on: <http://myweb.tiscali.co.uk/clydebridge/History\%20of\%20Steel\%20Plant.htm\#Fritz>. 
